\title{
The use of Passeriformes in the eastern Amazonia of Brazil: culture encourages hunting and profit encourages trade-CORRIGENDUM
}

\author{
Samantha Silva, Brenda Braga, Leandro Brasil \\ PEDRo BAía - Júnior and Diva Guimarẽes
}

DOI: doi.org/10.1017/S0030605320000551. Published online by Cambridge University Press, 17 December 2021.

In the original publication of this article, the scientific name of the bird pictured in Plate $1 \mathrm{c}$ was incorrect. The correct species name is Saltator coerulescens, not Saltator maximus.

\section{Reference}

Silva, S., Braga, B., Brasil, L., Baía-Júnior, P. \& Guimarães, D. (2021) The use of Passeriformes in the eastern Amazonia of Brazil: culture encourages hunting and profit encourages trade. Oryx, $56,218-227$. 